\title{
Rancang Bangun Sistem Reservasi Kamar pada Manadia Guest House Manado berbasis Web
}

\author{
Fergie Joanda Kaunang \\ Fakultas Teknologi Informasi, Universitas Advent Indonesia \\ e-mail: fergie.kaunang@unai.edu
}

\begin{abstract}
Abstrak
Perkembangan dunia teknologi saat ini mengalami perkembangan yang semakin pesat. Teknologi informasi tidak lagi hanya sekedar bidang ilmu namun juga menjadi suatu bagian yang lekat dengan dunia bisnis, industri, pendidikan dan hubungan sosial. Bisnis penginapan adalah salah satu bisnis yang sedang berkembang oleh karena bisnis penginapan beroperasi selama 24 jam perhari sepanjang tahun tanpa pengecualian mengenai hari libur. Kesempatan ini dapat menjadi salah satu peluang untuk dunia industri termasuk industri perhotelan untuk memanfaatkan kemajuan teknologi informasi dengan mengembangkan sistem terkomputerisasi yang dapat menjadi sarana untuk memudahkan konsumen ataupun mereka yang menggunakan jasa layanan hotel/penginapan. Dengan dikembangkannya sistem yang terkomputerisasi maka proses-proses seperti pemesanan kamar, penyajian informasi kepada konsumen dapat dilakukan dengan mudah. Penelitian bermaksud untuk merancang suatu sistem reservasi kamar pada salah satu penginapan di kota Manado yakni Manadia Guest House. Analisis dan perancangan sistem dalam penelitian ini menggunakan metode pendekatan UML (Unified Modeling Language), sedangkan pengembangan sistem menggunakan metode Prototyping. Hasil dari penelitian ini merupakan rancangan sistem yang terkomputerisasi di mana dapat digunakan untuk memudahkan dan meningkatkan jalannya proses bisnis yang ada pada Manadia Guest House.
\end{abstract}

Kata Kunci: Analisis dan Perancangan Sistem, Metode Prototyping, Unified Modeling Language (UML), Sistem Reservasi

\section{Design of Room Reservation Web-based System At Manadia Guest House Manado}

\begin{abstract}
The development of the technological world is currently experiencing increasingly rapid development. Information technology is no longer just a field of science but also an integral part of the world of business, industry, education and social relations. The hotel or lodging business is one of the growing businesses because it operates 24 hours a day throughout the year without exception regarding holidays. This can be one of the opportunities for the industrial world including the hotel industry to take advantage of advances in information technology by developing computerized systems that can be a means to facilitate those that hotel or lodging services. With the development of a computerized system, processes such as booking a room, providing information to consumers can be done easily. This research aims to design a room reservation system in one of the inns in the city of Manado, Manadia Guest House. The analysis and design of the system in this study uses the UML (Unified Modeling Language) approach, while the system development uses the Prototyping method. The results of this study are a computerized system designs which can be used to facilitate and improve the business processes that exist at Manadia Guest House.
\end{abstract}

Keywords: System Analysis and Design, Prototyping Method, Unified Modeling Language (UML), Reservation System 


\section{Pendahuluan}

Teknologi informasi saat ini sudah merambah dan banyak digunakan di berbagai bidang. Sistem yang terkomputerisasi telah menjadi salah satu alat yang wajib dimiliki oleh perusahaan ataupun instansi untuk dapat mempercepat proses bisnis serta menghasilkan informasi yang akurat, tepat dan terintegrasi. Salah satu contoh sistem yang telah banyak digunakan saat ini yakni sistem informasi berbasis web. Banyak pelaku bisnis menggunakan website sebagai sarana promosi bisnis ataupun sekedar menyediakan informasi bagi para pelanggan ataupun calon pelanggan mereka. Indonesia memiliki banyak tempat yang dapat dijadikan destinasi wisata. Saat ini, pemerintah Indonesia menetapkan sektor pariwisata sebagai salah satu prioritas pembangunan nasional [1-3]. Hal ini berdampak pada semakin berkembangnya industri penginapan ataupun perhotelan.

Industri pariwisata dan perhotelan sendiri dianggap sebagai industri dengan perkembangan terbesar dan tercepat di dunia $[4,5]$. Bisnis penginapan adalah salah satu bisnis yang sedang berkembang oleh karena bisnis penginapan beroperasi selama 24 jam per hari sepanjang tahun tanpa pengecualian mengenai hari libur. Kesempatan ini dapat menjadi salah satu peluang untuk dunia industri termasuk industri perhotelan untuk memanfaatkan kemajuan teknologi informasi dengan mengembangkan sistem terkomputerisasi yang dapat menjadi sarana untuk memudahkan konsumen ataupun mereka yang menggunakan jasa layanan hotel/penginapan. Guest House merupakan suatu tempat penginapan yang menawarkan layanan sewa harian dan bulanan. Hal inilah yang membedakan Guest House dengan Hotel [6].

Manadia Guest House merupakan salah satu anak perusahaan dari Hotel Sutan Raja. Dengan keberadaan Manadia Guest House di Sulawesi Utara, memberi dukungan dalam hal pariwisata di Sulawesi Utara sendiri. Memiliki tiga cabang yang masing-masing bertempat pada Maumbi, Minahasa Utara Wenang, Manado - dan Malalayang, Manado, Manadia Guest House menyediakan 24 kamar bagi para pelanggannya dengan harga yang relatif murah. Penginapan ini juga memberikan layanan yang berbeda dibandingkan dengan hotel ataupun penginapan lainnya di mana tidak adanya waktu tertentu untuk checkin ataupun check-out sehingga tamu dapat check-in ataupun check-out kapan saja. Guest House ini juga memberikan fasilitas standar yang sama dengan penginapan lainnya. Saat ini, sistem pencatatan reservasi dari penginapan ini masih menggunakan sistem pencatatan manual di mana setiap reservasi begitu juga transaksi akan dicatat dalam satu buku oleh resepsionis. Hal ini menyebabkan timbulnya beberapa masalah antara lain masalah ketersediaan kamar dan waktu tunggu tamu yang baru akan menginap.

Tujuan dari penelitian ini yaitu untuk merancang suatu sistem reservasi kamar berbasis web di mana dengan adanya sistem reservasi kamar ini akan meningkatkan kualitas pelayanan begitu juga proses bisnis yang terjadi di Manadia Guest House. Sistem yang akan dibangun akan memberikan fitur untuk pencatatan data pelanggan secara terkomputerisasi di mana data pelanggan kemudian akan disimpan dalam database. Sistem ini juga akan menyediakan informasi ketersediaan kamar serta pencatatan transaksi yang ada dalam Manadia Guest House. Dengan dirancangnya sistem ini pelayanan serta reservasi dilakukan lebih cepat dan akurat.

\section{Metode Penelitian}

Metode yang digunakan untuk merancang sistem reservasi kamar ini adalah metode Prototyping. Metode ini menitikberatkan pada pembuatan purwarupa dari suatu aplikasi atau perangkat lunak ataupun juga sistem. Secara khusus metode ini menunjukkan beberapa aspek dari sistem yang akan dibangun namun belum tentu benar-benar sama dengan hasil akhir [7]. Prototyping sendiri digunakan untuk pengembangan perangkat lunak ataupun sistem di mana kebutuhan dari sistem belum jelas diketahui atau belum lengkap [8]. Dalam metode ini terdapat 5 tahapan (Gambar 1 [8]) yang harus dilalui pada saat pengembangan sistem dalam penelitian ini yaitu:

1. Communication: merupakan tahap pengumpulan data untuk memenuhi kebutuhan penelitian di mana data yang dibutuhkan merupakan data yang menjadi persyaratan dari penelitian ini. 
Dalam memperoleh data, peneliti melakukan komunikasi secara langsung dengan manager Manadia Guest House. Peneliti mengumpulkan data spesifikasi kebutuhan sistem dengan melakukan wawancara dan observasi langsung dengan pihak yang bersangkutan yakni pihak manajemen Manadia Guest House. Peneliti melakukan wawancara dengan manager Manadia Guest House mengenai proses bisnis apa saja yang ada pada Manadia Guest House, sejarah berdirinya serta masalah apa saja yang dihadapi dalam reservasi kamar. Dari tahapan ini, peneliti memperoleh data primer dan sekunder untuk penelitian ini.

2. Quick Plan: merupakan tahapan di mana peneliti membuat perencanaan terhadap apa saja yang akan dilakukan sesuai dengan data yang telah dikumpulkan pada tahapan sebelumnya. Setelah memperoleh data untuk penelitian, langkah selanjutnya yang dilakukan adalah pembuatan suatu rencana pengembangan sistem.

3. Modeling Quick Design: pada tahap ini peneliti membuat suatu model perancangan yang dibutuhkan dalam penelitian dan merupakan dasar pembuatan purwarupa. Rancangan yang dibuat adalah rancangan sederhana dari sistem yang akan dikembangkan. Rancangan ini dibuat berdasarkan data yang telah dikumpulkan maupun spesifikasi kebutuhan yang telah dipaparkan oleh pengguna pada tahapan sebelumnya.

4. Construction of Prototype: merupakan tahap pengembangan purwarupa sesuai dengan model perancangan yang telah dilakukan pada proses sebelumnya. Proses pengembangan disesuaikan dengan data yang telah dikumpulkan, direncanakan, dan dirancang sebelumnya.

5. Development Delivery and Feedback: di tahap ini peneliti menyerahkan purwarupa yang telah dibuat kepada stakeholder dalam hal ini pihak manajemen Manadia Guest House untuk kemudian dievaluasi dan diberikan umpan-balik dari stakeholder apakah sudah sesuai dengan tujuan atau belum. Apabila masih terdapat kekurangan ataupun belum sesuai dengan tujuan maka proses akan berulang kembali ke tahap pertama.

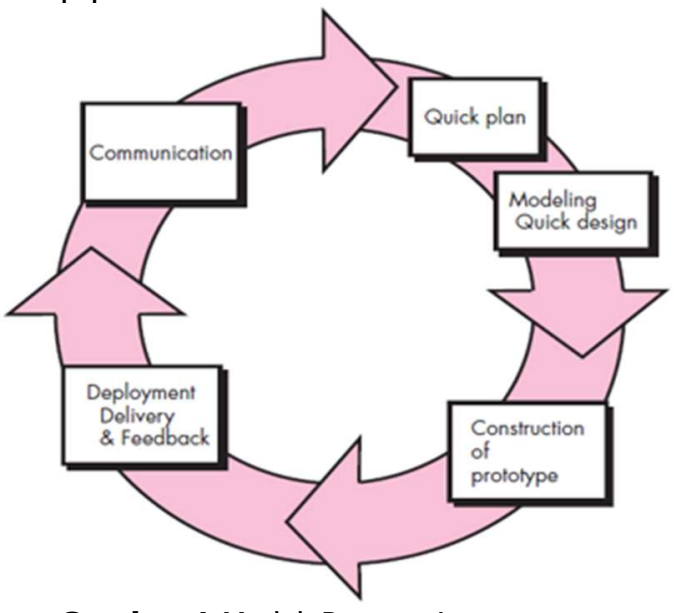

Gambar 1 Model Prototyping

Penelitian ini menggunakan metode Prototyping oleh karena metode atau model ini memiliki kelebihan di mana pengembangan sistem dapat dilakukan secara berkelanjutan walaupun spesifikasi kebutuhan belum lengkap. Setiap tahapan dapat dilakukan secara berulang apabila ditemukan masih ada kekurangan ataupun perubahan.

\section{Hasil Analisis dan Perancangan}

Sistem Reservasi Kamar Manadia Guest House menggunakan UML (Unified Modeling Language) untuk menggambarkan dengan memvisualisasikan rancangan sistem yang telah di kembangkan. Perancangan dan pembuatan sistem ini merupakan jawaban dari perumusan masalah yang telah di kemukakan oleh penulis, yaitu bagaimana mengembangkan suatu perangkat lunak Sistem Reservasi Kamar berbasiskan 
web pada Manadia Guest House dengan operasional offline. UML sendiri adalah suatu Bahasa yang digunakan untuk mendefinisikan syarat-syarat sistem (system requirements), membuat analisis dan perancangan sistem, serta mendeskripsikan arsitektur dalam pemrograman berorientasi objek [9-12]. Sistem yang di kembangkan ini memiliki 2 bagian utama dari sisi user, yaitu antarmuka pada sisi Receptionist dan pada sisi Manager. Antarmuka pada sisi Receptionist merupakan penggunaan sistem untuk menjalankan proses bisnis reservasi kamar pada Manadia Guest House yang dapat melayani checkin dan check-out customer. Sedangkan pada sisi Manager merupakan penggunaan sistem untuk pemantauan data keuangan dan data pelanggan.

\section{Unified Modeling Language (UML)}

Unified modeling language atau UML adalah salah satu "bahasa" ataupun notasi yang saat ini telah menjadi standar dalam dokumentasi, perancangan serta pembangunan perangkat lunak [13-15]. UML sendiri telah banyak digunakan untuk memodelkan sistem baik skala kecil maupun skala besar dan paling banyak digunakan untuk pengembangan sistem ataupun perangkat lunak yang berorientasi objek. UML sendiri merupakan gabungan dari 3 metode atau notasi yang sudah ada sebelumnya yakni Booch, Rumbaugh dan Jacobson [16]. Dalam UML, diagram digunakan untuk menggambarkan atau mengilustrasikan aspek atau bagian tertentu dari sistem yang merupakan representasi dari sudut pandang tertentu $[13,14]$. Penelitian ini menggunakan 4 diagram UML dalam merancang dan mengembangkan sistem reservasi kamar pada Manadia Guest House.

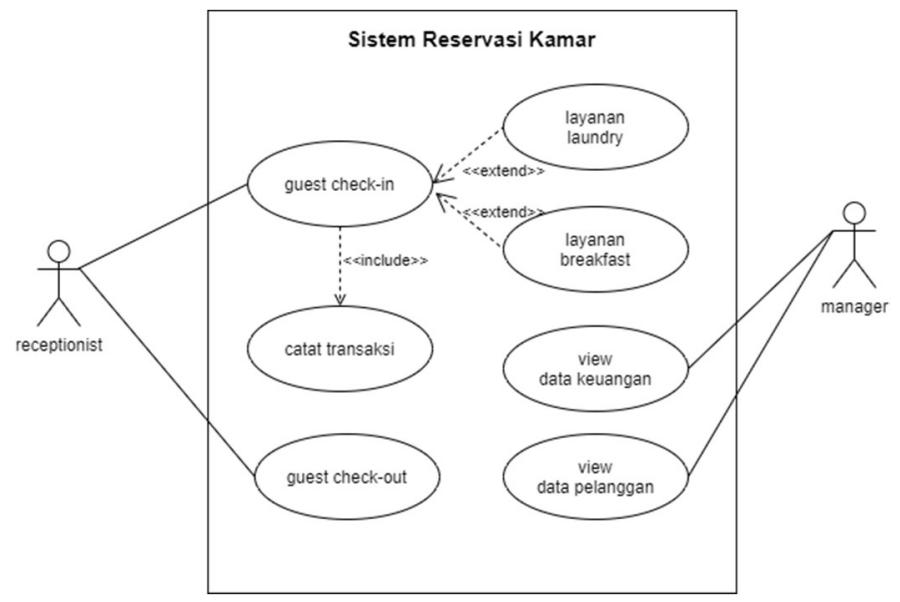

Gambar 2 Use Case Diagram Sistem Reservasi Kamar Manadia Guest House

\section{Use Case Diagram}

Use Case Diagram adalah diagram yang menggambarkan deskripsi fungsi dari sistem atau pun juga menunjukkan interaksi antara pengguna dengan sistem [17]. Diagram ini memberikan gambaran relasi antara actor dan use case. Actor merepresentasikan pengguna dari sistem ataupun sistem lain yang berinteraksi dengan sistem yang sedang dikembangkan, sedangkan suatu use case merupakan pandangan eksternal dari sistem yang mewakili beberapa tindakan yang mungkin dilakukan pengguna untuk menyelesaikan suatu tugas ataupun tujuan tertentu. Gambar 2 adalah diagram use case dari penelitian ini.

Terdapat 2 aktor atau pengguna yang akan menggunakan sistem reservasi kamar yang akan dibangun ini yakni resepsionis dan manager. Dapat dilihat pada gambar 2 bahwa sistem ini memiliki 5 fungsionalitas utama dan 2 fungsionalitas tambahan. Fitur pertama yakni guest check-in yang merupakan fitur yang memungkinkan resepsionis untuk mencatat ke dalam sistem ketika ada tamu yang akan menginap di Manadia Guest House. Setelah check-in, resepsionis akan menawarkan layanan tambahan kepada tamu yakni layanan laundryataupun layanan breakfast. Penghitungan total biaya menginap akan dilakukan pada use case catat transaksi. Sistem ini tidak memberikan pilihan metode pembayaran oleh karena pihak Manadia Guest House hanya melayani pembayaran dengan menggunakan uang tunai. Apabila tamu 
Rancang Bangun Sistem Reservasi Kamar pada Manadia Guest House Manado berbasis Web

meminta layanan tambahan seperti layanan laundry maka resepsionis akan memasukkan biaya berdasarkan banyaknya pakaian dari tamu. Layanan tambahan lainnya yakni layanan breakfast. Layanan ini merupakan layanan tambahan apabila tamu menginginkan sarapan pagi selama periode inap ataupun hari-hari tertentu sesuai dengan permintaan tamu.

Fitur selanjutnya adalah guest check-out di mana resepsionis akan melakukan pencatatan tanggal check-out dari tamu kemudian melakukan pemeriksaan kamar sebelum tamu meninggalkan penginapan. Fungsionalitas selanjutnya yakni view data keuangan di mana fungsionalitas ini hanya dapat dilakukan oleh manager. Hal yang sama juga berlaku untuk use case view data pelanggan atau tamu.

\section{Class Diagram}

Class Diagram merupakan diagram dengan susunan kelas-kelas yang memiliki asosiasi satu dengan yang lain. Dalam diagram ini hubungan antar kelas digambarkan dengan multiplicity [18]. Rancangan kelaskelas yang dimiliki oleh sistem reservasi kamar ini dapat dilihat pada gambar 3. Class Diagram pada gambar 3 memiliki 13 buah class yakni class guest, class receptionist, class manager, class kamar, class check-in, class check-out, class employee, class data keuangan, class login, class layanan, class laundry, class breakfast, dan class pembayaran. Atribut data yang dimaksud pada class check-in dan check-out adalah data tanggal check-in begitu juga check-out dari tamu.

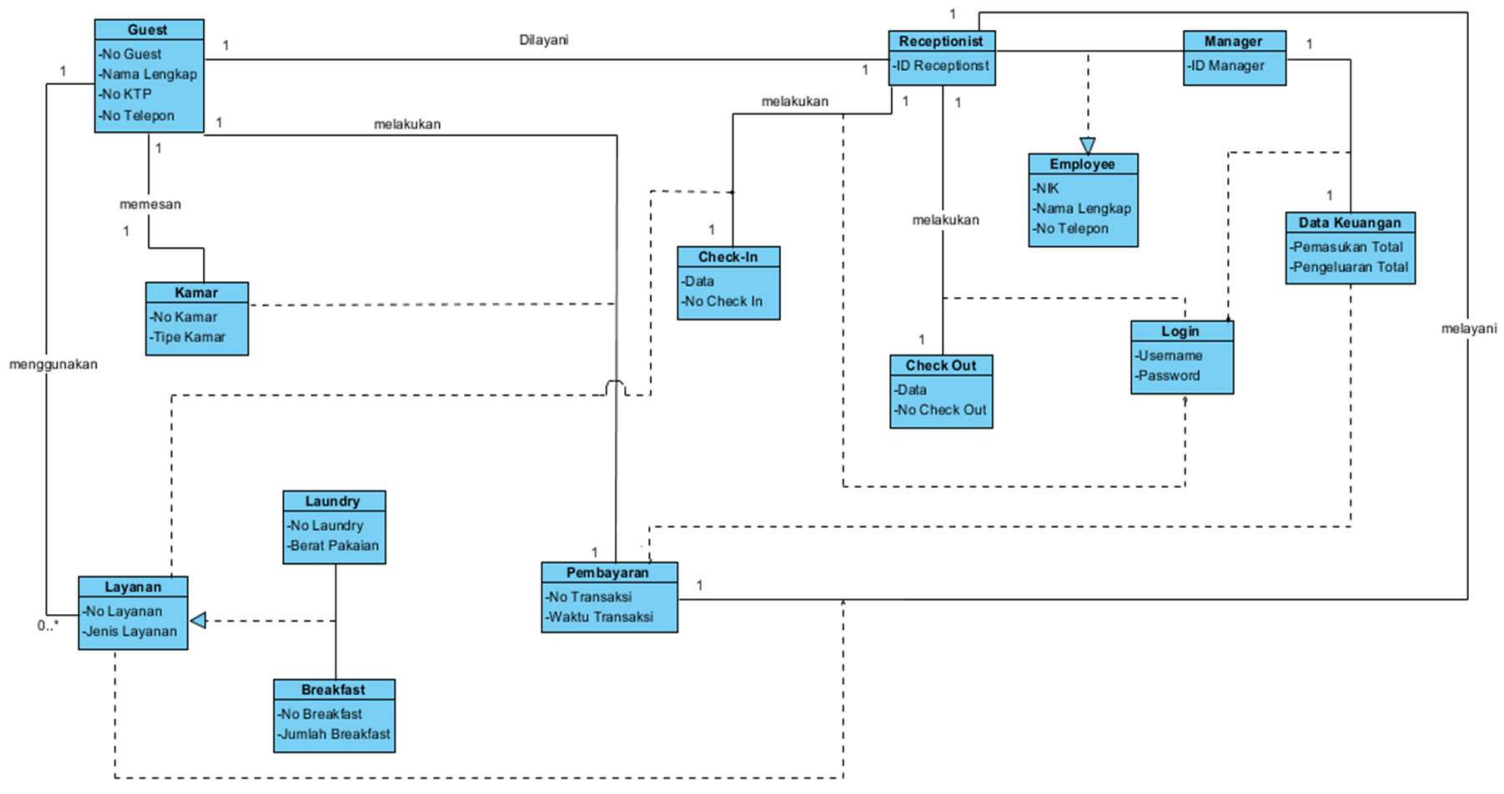

Gambar 3 Class Diagram Sistem Reservasi Kamar Manadia Guest House

\section{Activity Diagram}

Dalam merepresentasikan alur kerja dari aktifitas dan tindakan bertahap dengan dukungan untuk pilihan, iterasi dan konkurensi juga untuk memodelkan komputasi dan organisasi dari Sistem Reservasi Kamar Manadia Guest House peneliti menggunakan Activity Diagram. Activity Diagram sendiri adalah diagram UML yang bermanfaat untuk memodelkan alur kerja dari suatu sistem [10, 19]. Gambar 4 dan gambar 5 adalah Activity Diagram dari masing-masing proses check-in dan check-out. Pada proses checkin resepsionis harus login terlebih dahulu ke dalam sistem. Setelah berhasil login maka resepsionis kemudian dapat memilih menu check-in dan memasukkan data dari tamu yang akan menginap. Pada saat proses check-in resepsionis akan menawarkan layanan tambahan yakni layanan laundry dan layanan breakfast. Apabila tamu ingin menggunakan kedua layanan tersebut maka sistem akan mengalihkan ke halaman khusus untuk masing-masing layanan tambahan yang ada. 


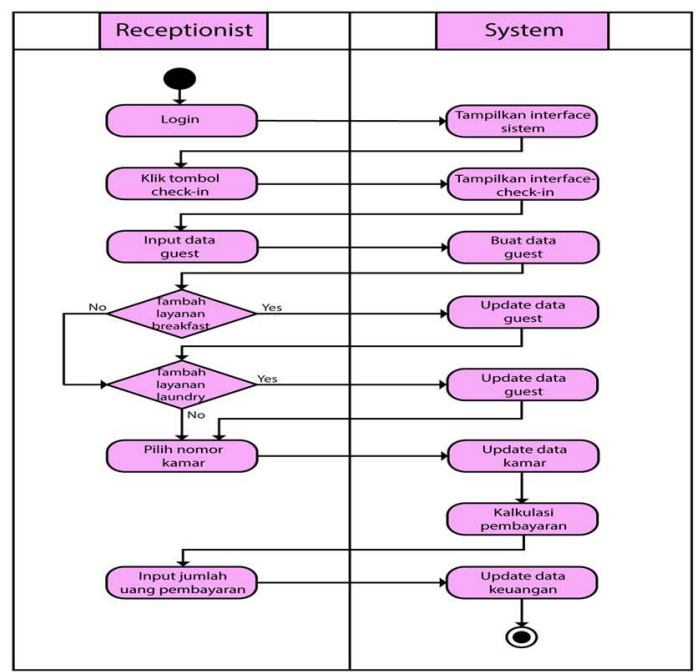

Gambar 4 Activity Diagram untuk Use Case Guest Check-In

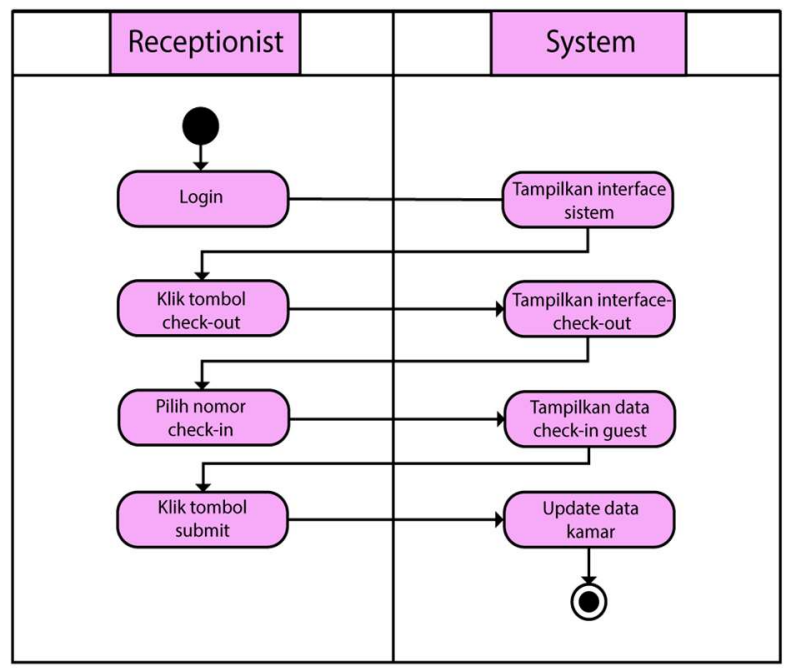

Gambar 5 Activity Diagram untuk Use Case Guest Check-Out

Aktivitas yang terjadi pada saat proses check-out yakni dalam halaman check-out resepsionis hanya perlu memilih nomor check-in kemudian sistem akan mengubah data dan status kamar.

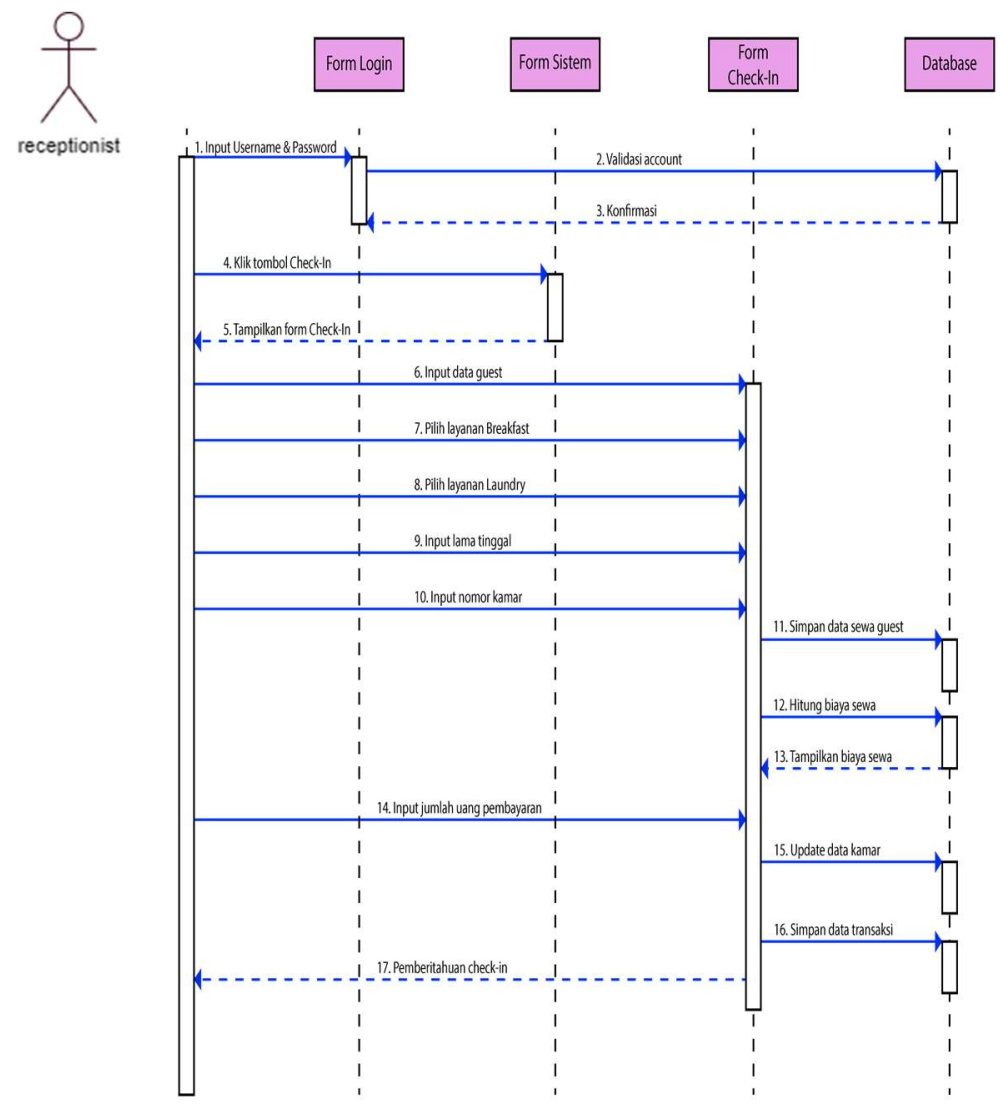

Gambar 6 Sequence Diagram untuk Proses Check-In 


\section{Sequence Diagram}

Sequence Diagram memberikan deskripsi mengenai interaksi antar sejumlah objek dalam urut-urutan waktu. Manfaat dari diagram ini adalah untuk menampilkan rangakaian yang dikirimkan antara satu objek dengan objek lainnya [6]. Gambar 6 dan Gambar 7 adalah Sequence Diagram untuk masing-masing proses check-in dan check-out.

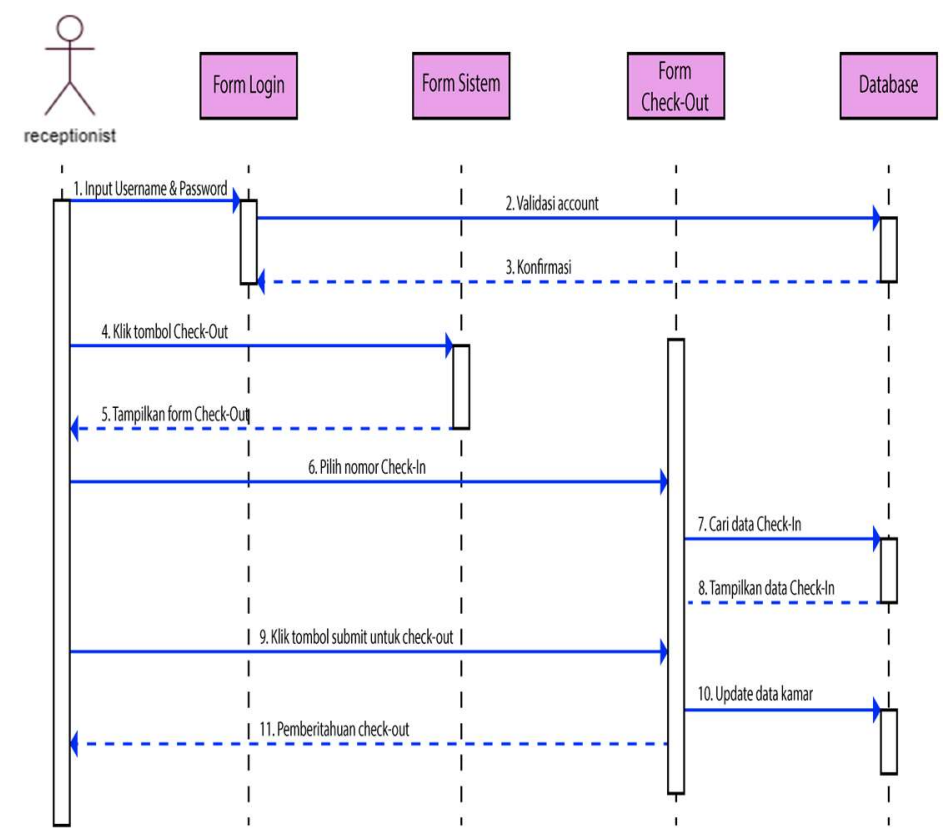

Gambar 7 Sequence Diagram untuk Proses Check-out

\section{Perancangan Antarmuka}

Dalam mengembangkan sistem tahapan yang dilakukan setelah analisis kebutuhan sistem adalah proses perancangan sistem. Proses perancangan sistem sendiri meliputi proses untuk mendefinisikan kebutuhan fungsional maupun gambaran arsitektur sistem sebelum diimplementasikan. Dalam penelitian ini diberikan rancangan antarmuka dari sistem yang akan dikembangkan. Gambar 8 dan gambar 9 merupakan rancangan antarmuka menu utama untuk receptionist setelah berhasil login ke dalam sistem. Gambar 10 merupakan rancangan antarmuka bagi manager untuk dapat melihat data keuangan.

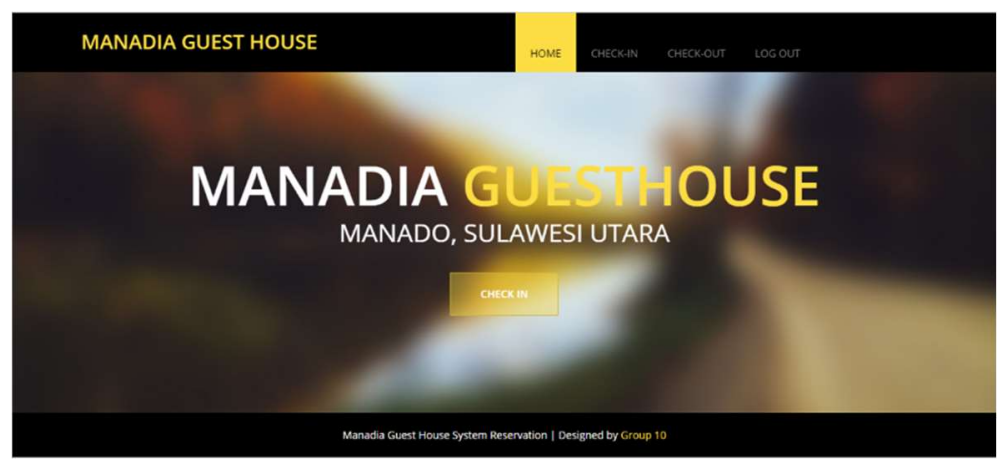

Gambar 8 Rancangan Antarmuka menu utama untuk resepsionis 


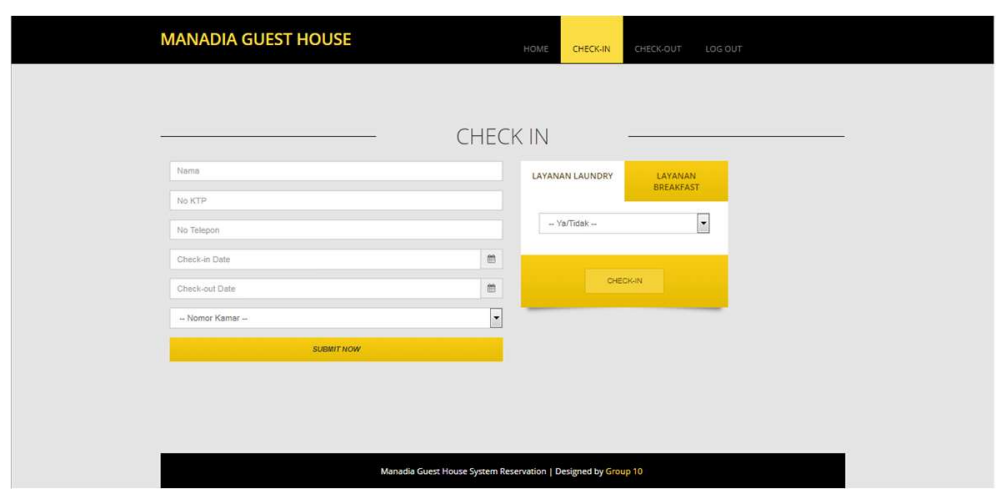

Gambar 9 Rancangan Antarmuka untuk pengisian data tamu oleh resepsionis

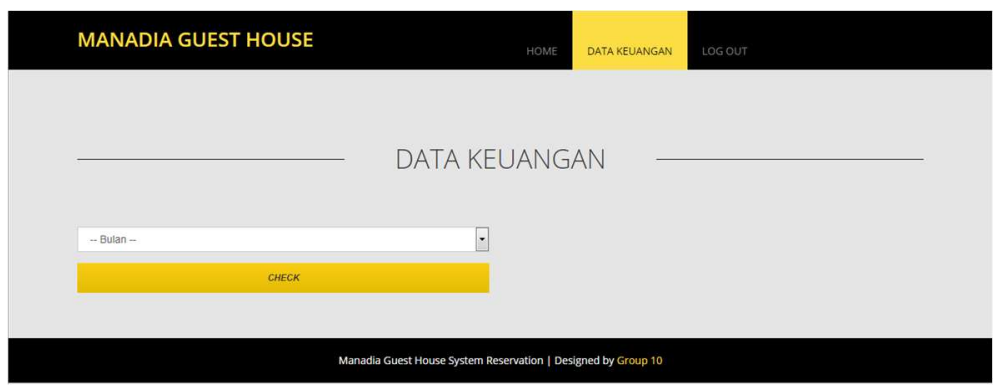

Gambar 10 Rancangan Antarmuka untuk melihat data keuangan dari sisi manager

\section{Kesimpulan}

Perancangan sistem reservasi kamar yang sudah terkomputerisasi ini diharapkan dapat membantu sistem reservasi kamar dan meningkatkan jalannya proses bisnis yang ada pada Manadia Guest House. Sistem ini juga dapat memudahkan manager Manadia Guest House dalam memantau data keuangan. Namun, peneliti menyadari masih terdapat kekurangan mengingat sistem yang dikembangkan merupakan sistem offline di mana sistem terbatas hanya dapat digunakan pada satu perangkat komputer saja. Pada penelitian lanjutan dapat dikembangkan implementasi dari sistem ini dan dibuat menjadi sistem reservasi online yang dapat memberikan lebih banyak kemudahan baik bagi pengguna juga bagi para pihak pengambil keputusan mengingat sistem yang dikembangkan ini masih menggunakan jaringan localhost.

\section{Daftar Pustaka}

[1] indonesia.go.id. (2019, 18 Maret). Wisata Indonesia di Mata Dunia [Online]. Available: https://indonesia.go.id/ragam/pariwisata/pariwisata/wisata-indonesia-di-mata-dunia.

[2] B. A. Simanjuntak, F. Tanjung, and R. Nasution, Sejarah pariwisata: menuju perkembangan pariwisata Indonesia. Yayasan Pustaka Obor Indonesia, 2017.

[3] R. Evita, I. N. Sirtha, and I. N. Sunartha, "Dampak perkembangan pembangunan sarana akomodasi wisata terhadap pariwisata berkelanjutan di bali," Jurnal Ilmiah Pariwisata. Denpasar: Universities Udayana.(16 Juni 2014, 6: 05 PM), 2012.

[4] J. Anuar, M. Musa, and K. Khalid, "Smartphone's application adoption benefits using mobile hotel reservation system (MHRS) among 3 to 5-star city hotels in Malaysia," Procedia-Social and Behavioral Sciences, vol. 130, no. 0, pp. 552-557, 2014. 
[5] J. R. Walker and J. T. Walker, Introduction to hospitality management. Prentice Hall Upper Saddle River, NJ, 2004.

[6] I. Maita and A. Adawiyah, "Sistem Informasi Reservasi Online Pada Guest House Uin Suska Riau Berbasiskan Web," Jurnal IImiah Rekayasa dan Manajemen Sistem Informasi, vol. 3, no. 1, pp. 85-96, 2017.

[7] W. Scacchi, "Process models in software engineering," Encyclopedia of software engineering, 2002.

[8] R. S. Pressman, Software engineering: a practitioner's approach. Palgrave Macmillan, 2005.

[9] J. RUMBAUGH, I. JACOBSON, and G. BOOCH, "Unified modeling language reference manual, the.[SI]: Pearson Higher Education, 2004," Citado na, p. 55.

[10] G. Booch, J. Rumbaugh, and I. Jackobson, "UML: Unified Modeling Language," ed: Versão, 1997.

[11] S. Bennett, S. McRobb, and R. Farmer, Object-oriented systems analysis and design using UML. McGraw Hill Higher Education, 2005.

[12] C. Larman, Applying UML and patterns: an introduction to object oriented analysis and design and interative development. Pearson Education India, 2012.

[13] D. Rosenberg and K. Scott, Use case driven object modeling with UML. Springer, 1999.

[14] T. von der Maßen and H. Lichter, "Modeling variability by UML Use Case Diagrams," in Proceedings of the International Workshop on Requirements Engineering for product lines, 2002: Citeseer, pp. 19-25.

[15] N. Medvidovic, D. S. Rosenblum, D. F. Redmiles, and J. E. Robbins, "Modeling software architectures in the Unified Modeling Language," ACM Transactions on Software Engineering and Methodology (TOSEM), vol. 11, no. 1, pp. 2-57, 2002.

[16] A. Suhendar and H. Gunadi, "Visual Modeling," ed: Menggunakan UML dan Rational Rose, Informatika, Bandung, 2002.

[17] S. Sengupta and S. Bhattacharya, "Formalization of UML Use Case Diagram-a Z notation based approach," in 2006 International Conference on Computing \& Informatics, 2006: IEEE, pp. 1-6.

[18] J. W. Satzinger, R. B. Jackson, and S. D. Burd, Systems analysis and design in a changing world. Cengage learning, 2011.

[19] H. Kim, S. Kang, J. Baik, and I. Ko, "Test cases generation from UML Activity Diagrams," in Eighth ACIS International Conference on Software Engineering, Artificial Intelligence, Networking, and Parallel/Distributed Computing (SNPD 2007), 2007, vol. 3: IEEE, pp. 556-561. 